\title{
Development of a droplet digital PCR method for detection of Streptococcus agalactiae
}

\author{
Yi-Fan Zeng ${ }^{1,2,3,4+}{ }^{+}$Chu-Mao Chen ${ }^{1,2 \dagger}$, Xiao-Yan Li ${ }^{5+}$, Jun-Jiang Chen ${ }^{1,2,3}$, Yan-Ge Wang ${ }^{1,2,3}$, Shi Ouyang ${ }^{6}$,
} Tian-Xing Ji ${ }^{7}$, Yong Xia ${ }^{1,2,3}$ and Xu-Guang Guo ${ }^{1,2,3,8,9,10^{*}}$

\begin{abstract}
Background: Streptococcus agalactiae (GBS) is the causative pathogen of puerperal sepsis in pregnant women and pneumonia, sepsis and meningitis in infants. Infection of GBS is responsible for the increased morbidity in pregnant women and the elderly, and bring challenges to clinical diagnosis and treatment. However, culture-based approaches to detect S.agalactiae is time-consuming with limited sensitivity. Besides, real-time quantitative PCR demands expensive instruments with tedious steps. Thus, we aim to establish a new detection method for more accurate and rapid detection of S.agalactiae.
\end{abstract}

Results: The ddPCR primer targeted the CPSE gene showed better amplified efficiency in the reaction. The limit of detection for GBS DNA with ddPCR was able to reach $5 \mathrm{pg} / \mu \mathrm{L}$. Moreover, no positive amplified signals could be detected in the reactions which served 11 non-GBS strains DNA as templates. Furthermore, the coefficient of variation of this method was $4.5 \%$, indicating excellent repeatability of ddPCR assay.

Conclusions: In our study, ddPCR was performed as a rapid detection of S.agalactiae with high sensitivity and specificity. This technique can promote the accuracy of the diagnosis of GBS infection and provide a scientific basis for clinical treatment.

Keywords: Droplet digital PCR, Streptococcus agalactiae, Quantitation

\section{Background}

Streptococcus agalactiae (Group B Streptococcus, GBS) is a facultative anaerobic gram-positive opportunistic pathogen, which colonizes the gastrointestinal and genitourinary tract of approximately $30 \%$ of the healthy adults [1]. Moreover, infection with GBS is the main cause of pneumonia, septicemia and meningitis in

\footnotetext{
* Correspondence: gysygxg@gmail.com

${ }^{\dagger}$ Yi-Fan Zeng, Chu-Mao Chen and Xiao-Yan Li contributed equally to this work.

'Department of Clinical Laboratory Medicine, The Third Affiliated Hospital of Guangzhou Medical University, Guangzhou 510150, China

${ }^{2}$ Institution of Kingmed of Guangzhou Medical University, Guangzhou 510000, China

Full list of author information is available at the end of the article
}

neonates, and is especially responsible for the high morbidity rate of pregnant women [2-4]. So far, detection of Streptococcus agalactiae varies from culture-based methods to novel molecular tools $[5,6]$. Traditional culture is laborious and time-consuming with limited sensitivity. Although real-time qPCR and other rapid techniques, such as MALDI-TOF-MS, are now commercialized, the cost and expertise limit their use in most laboratories [7]. Therefore, early diagnosis of infection requires a novel method with rapid and specificity in the detection of GBS.

Recently, droplet digital PCR (ddPCR) has been utilized in quantifying nucleic acid and detecting pathogens [8-10]. This method dilutes and divides the mixtures into many microdroplets with oil. Each microdroplet is

(c) The Author(s). 2020 Open Access This article is licensed under a Creative Commons Attribution 4.0 International License, which permits use, sharing, adaptation, distribution and reproduction in any medium or format, as long as you give appropriate credit to the original author(s) and the source, provide a link to the Creative Commons licence, and indicate if changes were made. The images or other third party material in this article are included in the article's Creative Commons licence, unless indicated otherwise in a credit line to the material. If material is not included in the article's Creative Commons licence and your intended use is not permitted by statutory regulation or exceeds the permitted use, you will need to obtain permission directly from the copyright holder. To view a copy of this licence, visit http://creativecommons.org/licenses/by/4.0/. The Creative Commons Public Domain Dedication waiver (http://creativecommons.org/publicdomain/zero/1.0/) applies to the data made available in this article, unless otherwise stated in a credit line to the data. 
amplified as an independent reaction system with or without target genes. The amplified condition of ddPCR is similar to that of real-time PCR with the probe for signal detection. Eventually, the absolute concentration will be calculated precisely according to the Poisson distribution without a standard curve [11-14].

Droplet digital PCR is an ultraprecise, reliable and economical method in the diagnosis of infectious disease. However, detection of GBS based on ddPCR has not been reported yet. Thus, we aim to evaluate the ddPCR for the detection of GBS and test whether ddPCR can be an alternative assay for the rapid diagnosis of GBS infection.

\section{Results}

Primer screening test

Two sets of primers showed different amplification to GBS ATCC13813 monitored by the SLAN-96P real-time system (Fig. 1). The amplified signal was firstly detected 15 cycles after the reaction and the peak emerged at approximately 45 cycles with $C p s E$ primer. No other amplification was seen in the Sip primer and negative control. Therefore, the CpsE primer was selected for the subsequent tests.

\section{Sensitivity and specificity of ddPCR for GBS}

The limit of ddPCR for detecting GBS DNA was able to reach $5 \mathrm{pg} / \mu \mathrm{L}$. As shown in Fig. 2, the horizontal axis represented the event number of four concentrations templates, and the vertical represented the sample amplitude. The positive and negative microdroplets were shown in blue and gray, respectively. The number of events was 0 in the concentration of $0.5 \mathrm{pg} / \mu \mathrm{L}$, suggesting no amplification in this reaction. (Fig. 3). No positive microdroplets could be detected in the reactions using non-GBS strains DNA as templates (data not shown). Therefore, the ddPCR with CpsE primer has a satisfactory sensitivity and specificity for GBS detection.

\section{Repeatability test of ddPCR}

GBS reference strain was run in triplicate (Fig. 4). The positive events number was 1661, 1560 and 1704, respectively, with a CV of $4.5 \%$, indicating that ddPCR has an excellent repeatability.

\section{Discussion}

Streptococcus agalactiae is the leading cause of neonatal pneumonia, infantile septicemia, bacterial meningitis, as well as perinatal infection of pregnant women $[15,16]$. Recently, a novel technique, ddPCR, was for DNA

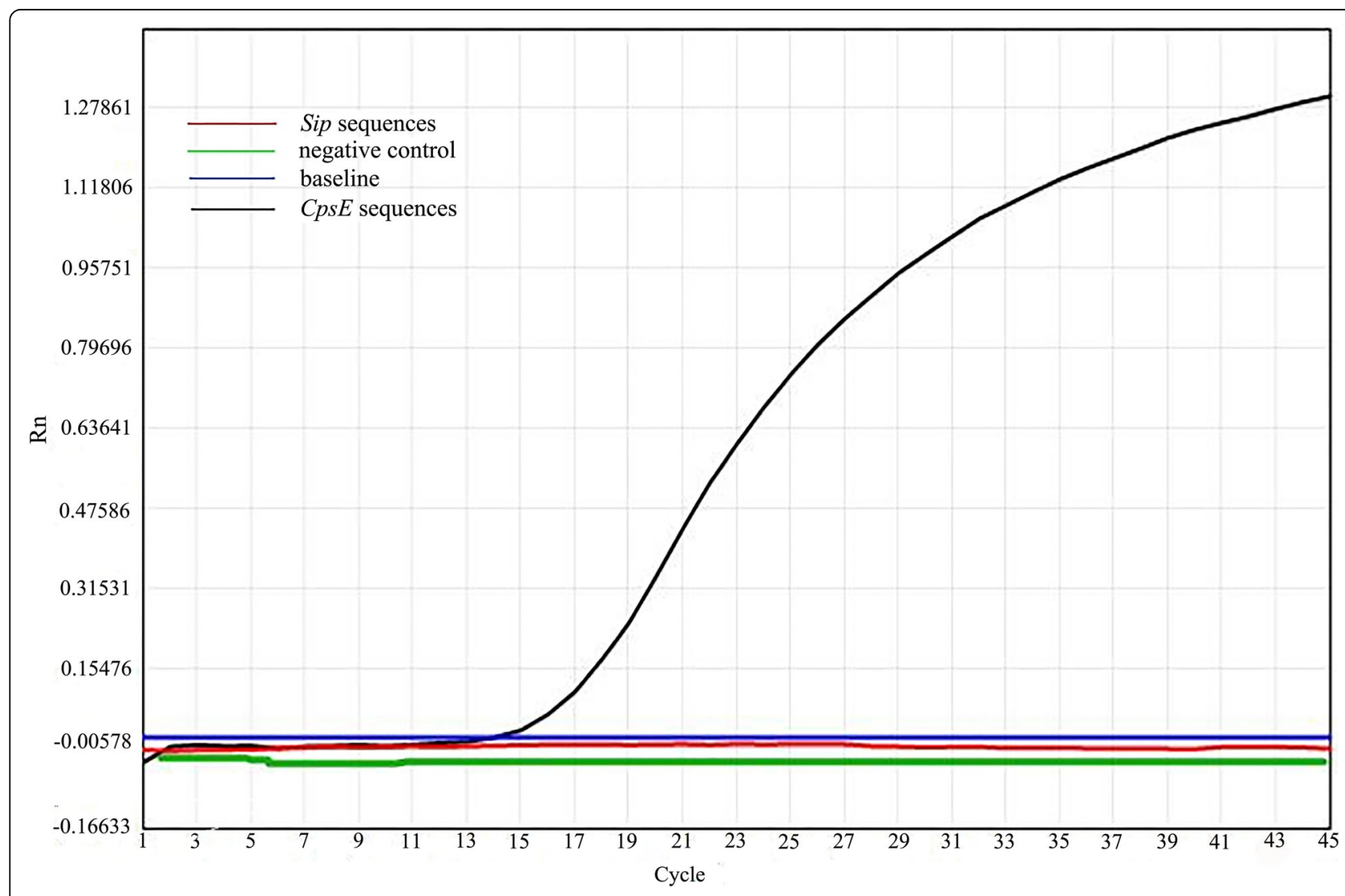

Fig. 1 The primer of the $\mathrm{qPCR}$ screening experiment in the present study 


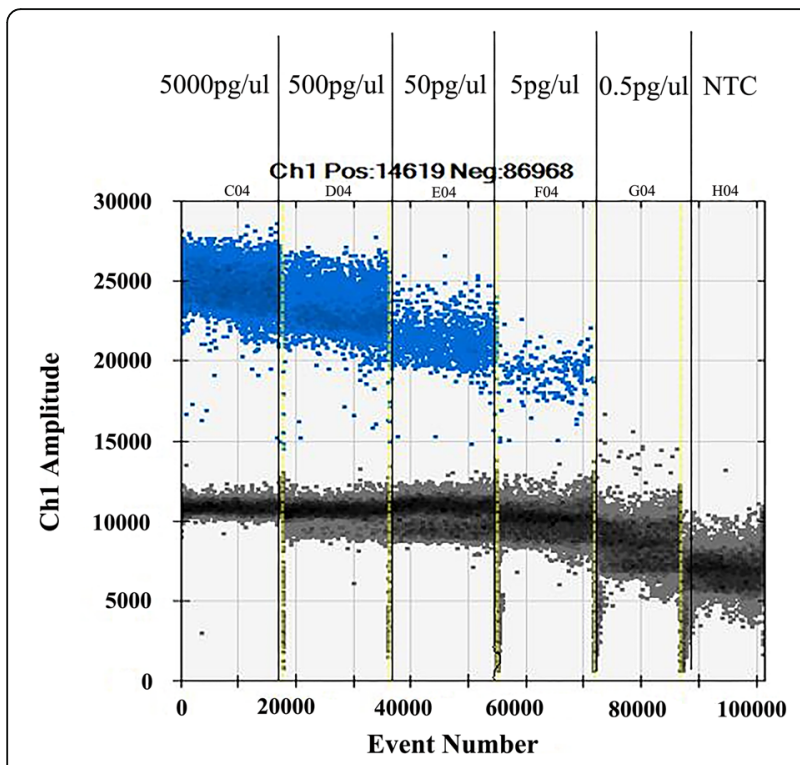

Fig. 2 Sensitivity assay for $d d P C R$ using continuous 10-fold dilutions of DNA templates from GBS ATCC13813

quantifications absolutely without depending on the standard curve [17]. Droplet digital PCR is the third generation PCR with higher diagnostic efficiency compared to conventional methods.

Currently, bacterial culture is the gold standard for the identification of GBS infection, but it is timeconsuming with limited sensitivity and vulnerable to interference [18]. Also, real-time qPCR requires expensive equipment and only quantifies nucleic acid relatively. In our study, we showed that ddPCR could detect S.agalactiae precisely as low as $5 \mathrm{pg} / \mu \mathrm{L}$. Moreover, amplification was observed in GBS but not in non-GBS strains, which indicated the high specificity of ddPCR primers. Furthermore, ddPCR had an excellent repeatability with a $\mathrm{CV}$ of $4.5 \%$. Given these advantages, it can be used to determine the expression and copy number variation analysis of the target gene $[19,20]$.

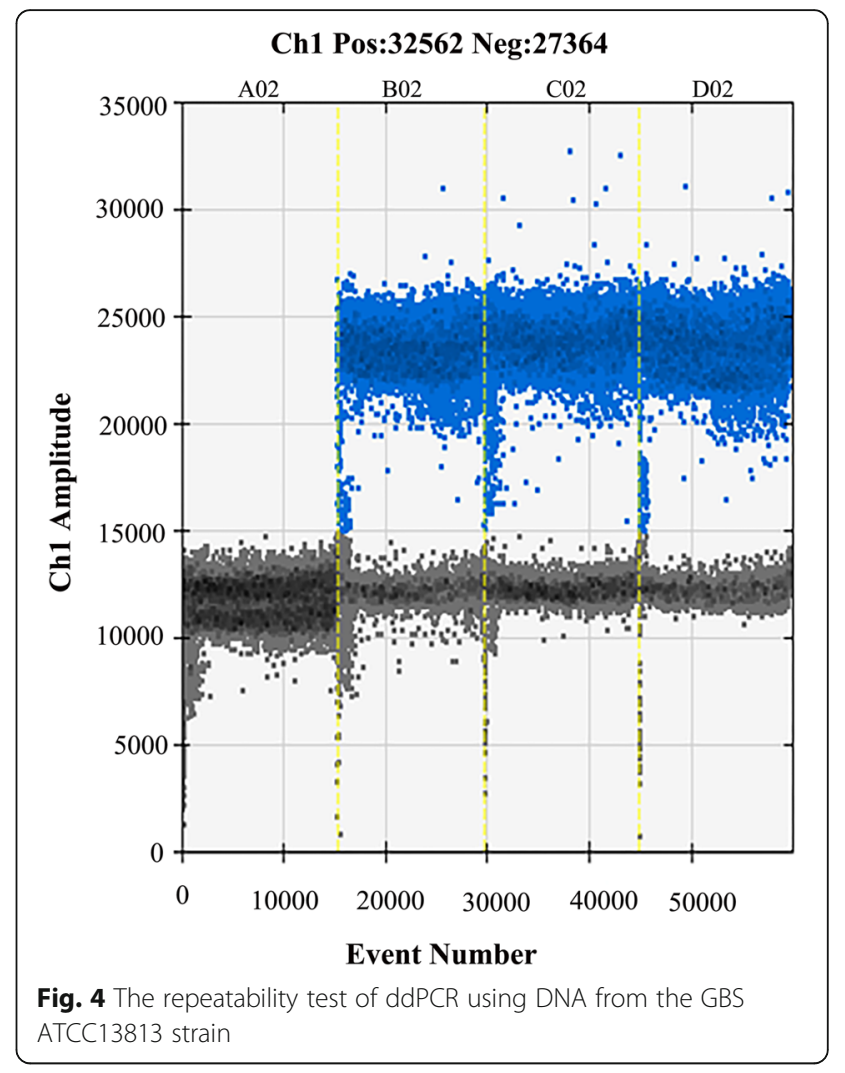

In the present study, the fluorescent dye EvaGreen which binds to dsDNA was used to monitor GBS, but it could cause false-positive results if there existed dimer formations. Thus, the melting curve was analyzed and no double-peak was found, indicating no primer dimer formation. Furthermore, we discovered that the CpsE primer amplified the target gene of GBS more effectively than the Sip gene.

Some limitations to our study should not be ignored. Firstly, ddPCR is an assay mainly with fluorescent probes. Application with EvaGreen dye may significantly interfere with the experimental results when the primer dimers were forming. Therefore, the demand for primers

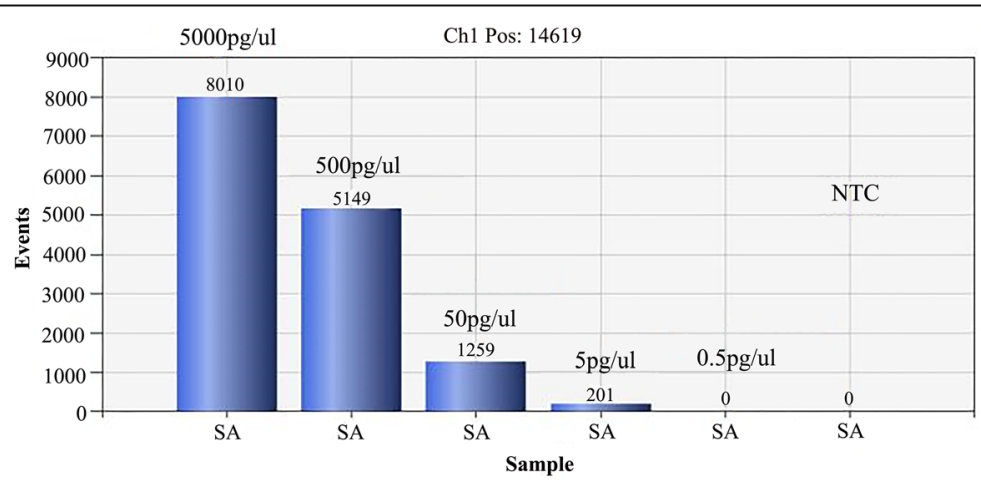

Fig. 3 The number of events in each amplification concentration 
specificity is very high. Secondly, bubbles in the process will produce less than 12,000 microdroplets. Thus the experiment does not meet the Poisson distribution, leading to inaccurate results. Thirdly, it was reported that the fbs-B gene was targeted with LAMP to identify GBS [5]. Which gene is more effective in detection needs to be further studied. Moreover, we just established a ddPCR method to identify GBS in the present study. However, given the small size of clinical samples that were collected difficultly, further validation should be considered with a larger sample in the next stage of our study. Meanwhile, since the purity of DNA templates are easily affected and varied from different samples, DNA extraction should be optimized to extend the ddPCR testing from the laboratory to further clinical detection.

\section{Conclusions}

In conclusion, our study suggested that ddPCR is a specific, economical and reliable method. However, further validation of larger clinical sample sets are necessary to confirm its value in diagnostic and prove that it is an alternative tool in the clinical detection of GBS.

\section{Methods}

\section{Bacterial strains}

GBS standard strain ATCC13813 was purchased from Shanghai cell bank of the Chinese Academy of Sciences. Eleven non-GBS strains were isolated from the Clinical Laboratory of Third Affiliated Hospital of Guangzhou Medical University and were initially identified by Matrix-Assisted Laser Desorption/Ionization Time of Flight Mass Spectrometry. Non-GBS strains stored at $70^{\circ} \mathrm{C}$, were used for specificity experiments, including Candida tropicalis, Candida albicans, Klebsiella pneumoniae, Streptococcus pyogenes, Acinetobacter baumannii, Escherichia coli, Staphylococcus haemolyticus, Candida parapsilosis, Streptococcus anginosus, Enterobacter aerogenes, Pseudomonas aeruginosa.

\section{DNA extraction}

The ATCC13813 and other non-GBS strains were inoculated onto sheep blood agar and cultured in $37^{\circ} \mathrm{C}$ constant thermostatic incubator for $18-24 \mathrm{~h}$. The bacterial colonies picked on the agar plates were inoculated into sterile physiological saline to prepare $1 \mathrm{ml}$ bacterial suspensions [21, 22]. Then the bacterial DNA was extracted and purified according to the instruction manuals of the TIANGEN DNA kit (TIANGEN BIOTECT, Beijing) and was stored at $-20^{\circ} \mathrm{C}$.

\section{Primer design and synthesis}

The sequences of Streptococcus agalactiae CpsE and Sip gene were obtained from GenBanK [23, 24]. Special primers were designed by Primer Premier 5.0(Premier
Laboratories, Canada) and synthesized by Thermo Scientific of Shanghai Trade Co. Ltd. (Table 1). The EvaGreen $^{\circ}$ dsDNA fluorescent dye (EvaGreen ${ }^{\circ}$ ) was used in this detection.

\section{Droplet digital PCR reaction}

The ddPCR reaction was performed in a QX200 Droplet Digital PCR System (Bio-Rad Laboratories, CA) according to the manufacturer's instruction [11]. Each test was prepared in a $20 \mu \mathrm{l}$ volume of the reaction mixture, which comprised $10 \mu \mathrm{L}$ of $2 \times \quad \mathrm{QX}^{200}{ }^{\mathrm{mix}} \mathrm{ddPCR}^{\mathrm{max}}$ EvaGreen ${ }^{\circ}$ Supermix (no dUTP; Bio-Rad), forward and reverse primers and $4 \mu \mathrm{L}$ of DNA templates. For microdroplets generation, 20ul mixture and $70 \mathrm{ul}$ droplet generation oil were added to the DG8 ${ }^{\text {in }}$ cartridge (Bio-Rad), then loaded into a QX200 Droplet Generator (Bio-Rad). Next, microdroplets were transferred into 96-well PCR plate and heat-sealed with foil to prevent aerosol pollution. Then the PCR was performed on a Bulk PCR Thermal Cycler using the following conditions: Pre-denature for 1 cycle at $95^{\circ} \mathrm{C}$ for $10 \mathrm{~min}$; denature for 45 cycles at $95^{\circ} \mathrm{C}$ for $15 \mathrm{~s}$; anneal and extend for 45 cycles at $60^{\circ} \mathrm{C}$ for $1 \mathrm{~min}$. Finally, the fluorescence signal in each plate was analyzed by a QX200 Droplet Reader and QuantaSoft $^{\mathrm{mm}}$ Version 1.7.4 [10, 25]. Each reaction adopted negative control and was performed in duplicate.

\section{Primer screening analysis}

Two sets of primers were dissolved into a working solution, and the DNA of the ATCC13813 strain was served as the template. Then the qPCR assay was performed to amplify CpsE or Sip gene in a SLAN-96P real-time system (HONGSHI. Shanghai). Briefly, we prepared a total volume of $25 \mu \mathrm{L}$ mixture according to the kit instructions, which contained DNA template, primers, SYBR GREEN dye and PCR Master Mix etc. The reaction procedure was set up identically as the ddPPCR amplification condition mentioned above. Finally, the amplification efficiency was compared to select a better primer for the subsequent assay.

\section{The sensitivity of ddPCR reaction}

DNA obtained from GBS reference strain ATCC13813 was used to determine the limitation of ddPCR assay towards the selected gene. The initial concentration of DNA was adjusted to $5 \mathrm{ng} / \mu \mathrm{L}$ and then diluted four

Table 1 Sequences of primers of the Sip and CPsE gene

\begin{tabular}{ll}
\hline Target & Sequences (5'-3') \\
\hline Sip upstream & CTGCCAACCACTATGACC \\
Sip downstream & CTGCTACAGTTCTTACCG \\
CpsE upstream & GCAAAAGAACAGATGGAACAAAGTG \\
CpsE downstream & CGCCGTAAGTAGCAACAGAT \\
\hline
\end{tabular}


times with sterile saline, i.e. $5000 \mathrm{pg} / \mu \mathrm{L}, 500 \mathrm{pg} / \mu \mathrm{L}, 50$ $\mathrm{pg} / \mu \mathrm{L}, 5 \mathrm{pg} / \mu \mathrm{L}$ and $0.5 \mathrm{pg} / \mu \mathrm{L}$. The ddPCR reaction was performed as described above with four concentrations of the DNA template to determine the sensitivity of ddPCR in the GBS test.

\section{Specificity and repeatability of ddPCR reaction}

The DNAs of the GBS ATCC13813 strain and other 11 non-GBS strains were used to assess the specificity of the primers under identical ddPCR conditions. For further repeatability analysis of ddPCR, the reaction was carried out by testing one positive strain and one negative strain three times under identical conditions. Finally, the fluorescence signal was evaluated.

\section{Abbreviations}

GBS: Group B Streptococcus (Streptococcus agalactiae); ddPCR: droplet digital PCR; MALDI-TOF-MS: Matrix-Assisted Laser Desorption/lonization Time-OfFlight Mass Spectrometry; LAMP: Loop-mediated isothermal Amplification; CV: Coefficient of Variation

\section{Acknowledgments}

We thank all members of our research team for their contributions to this work.

\section{Authors' contributions}

YFZ, JJC, XYL and XGG conceived and designed the study. YFZ, JJC and YGW cultured bacteria and carried out the dAPCR. CMC, SO and TXJ extracted DNA and performed the GPCR. YFZ, JJC, XYL and CMC conducted data analysis to make figures and tables. YX and XGG participated and gave guidance throughout the process. All members participated in the writing, review, discussion and revision of the manuscript and adopted the final version unanimously. The authors read and approved the final manuscript.

\section{Funding}

This study was supported by the "Climbing Plan" Guangdong University Student Science and Technology Innovation Cultivation Special Fund Projects (grant number pdjh2017b0421), the Science and Technology Innovation Project of Guangzhou Medical University (grant number 2016A046), the Natural Science Foundation of Guangdong Province (grant number 2015A030313684), the National Natural Science Foundation of China (grant number 81700004). The funding funders mentioned above had role in study design, experimental development, data collection, analysis and interpretation, and manuscript writing.

\section{Availability of data and materials}

All data generated or analyzed during this study are included in this published article.

\section{Ethics approval and consent to participate}

Not applicable.

\section{Consent for publication \\ Not applicable.}

\section{Competing interests}

The authors declare that there are no competing interests associated with the manuscript.

\footnotetext{
Author details

'Department of Clinical Laboratory Medicine, The Third Affiliated Hospital of Guangzhou Medical University, Guangzhou 510150, China. ${ }^{2}$ Institution of Kingmed of Guangzhou Medical University, Guangzhou 510000, China. ${ }^{3}$ Key Laboratory for Major Obstetric Diseases of Guangdong Province, Guangzhou 510150, China. ${ }^{4}$ iHuman Institute, ShanghaiTech University, Shanghai, China. ${ }^{5}$ The Fifth Affiliated Hospital, Southern Medical University, Guangzhou 510900, China. ${ }^{6}$ Department of Infectious Disease, The Fifth Affiliated Hospital
}

of Guangzhou Medical University, Guangzhou 510000, China. ${ }^{7}$ Department of Clinical Medicine, The Second Affiliated Hospital of Guangzhou Medical University, Guangzhou 511436, China. ${ }^{8}$ Department of Clinical Medicine, The Third Clinical School of Guangzhou Medical University, Guangzhou 511436, China. ${ }^{9}$ Key Laboratory of Reproduction and Genetics of Guangdong Higher Education Institutes, The Third Affiliated Hospital of Guangzhou Medical University, Guangzhou 510150, China. ${ }^{10}$ Stomatological Hospital of Guangzhou Medical University, Guangzhou 510150, China.

Received: 24 October 2019 Accepted: 15 June 2020

Published online: 23 June 2020

\section{References}

1. van der Mee-Marquet N, Fourny L, Arnault L, Domelier AS, Salloum M, Lartigue MF, et al. Molecular characterization of human-colonizing Streptococcus agalactiae strains isolated from throat, skin, anal margin, and genital body sites. J Clin Microbiol. 2008;46:2906-11. https://doi.org/10.1128/ jcm.00421-08.

2. Valkenburg-van den Berg AW, Houtman-Roelofsen RL, Oostvogel PM, Dekker FW, Dörr PJ, Sprij AJ. Timing of group B streptococcus screening in pregnancy: a systematic review. Gynecol Obstetric Investig. 2010;69:174-83. https://doi.org/10.1159/000265942.

3. Huber CA, McOdimba F, Pflueger V, Daubenberger CA, Revathi G. Characterization of invasive and colonizing isolates of Streptococcus agalactiae in east African adults. J Clin Microbiol. 2011;49:3652-5. https://doi. org/10.1128/jcm.01288-11.

4. Birlutiu V, Luca CM, Birlutiu RM. Streptococcus agalactiae meningoencephalitis associated with gastroesophageal reflux disease and chronic proton pump inhibitors use, in a 9 month-old infant: a case report. BMC Pediatr. 2018;18:21. https://doi.org/10.1186/s12887-018-0995-0.

5. Guo XG, Zhuang YR, Wen JZ, Xie TA, Liu YL, Zhu GD, et al. Evaluation of the real-time fluorescence loop-mediated isothermal amplification assay for the detection of Streptococcus agalactiae. Biosci Rep. 2019;39. https://doi.org/10. 1042/bsr20190383.

6. Furfaro LL, Chang BJ, Payne MS. Detection of group B streptococcus during antenatal screening in Western Australia: a comparison of culture and molecular methods. J Appl Microbiol. 2019;127:598-604. https://doi.org/10. 1111/jam.14331.

7. Rosa-Fraile M, Spellerberg B. Reliable detection of group B streptococcus in the clinical laboratory. J Clin Microbiol. 2017;55:2590-8. https://doi.org/10. 1128/jcm.00582-17.

8. Yan Y, Wang F, Zhang C, Jin X, Zhang Q, Feng X, et al. Evaluation of droplet digital PCR for non-invasive prenatal diagnosis of phenylketonuria. Anal Bioanalytical Chemistry. 2019. https://doi.org/10.1007/s00216-019-02087-4.

9. Li Z, Pan L, Lyu L, Li J, Jia H, Du B, et al. Diagnostic accuracy of droplet digital PCR analysis of cerebrospinal fluid for tuberculous meningitis in adult patients. Clin Microbiol Infect. 2019. https://doi.org/ 10.1016/j.cmi.2019.07.015.

10. Cheng X, Sun L, Zhao Q, Mi Z, Yu G, Wang Z, et al. Development and evaluation of a droplet digital PCR assay for the diagnosis of paucibacillary leprosy in skin biopsy specimens. PLoS Negl Trop Dis. 2019;13:e0007284. https://doi.org/10.1371/journal.pntd.0007284.

11. Hindson BJ, Ness KD, Masquelier DA, Belgrader P, Heredia NJ, Makarewicz $A J$, et al. High-throughput droplet digital PCR system for absolute quantitation of DNA copy number. Anal Chem. 2011;83:8604-10. https://doi. org/10.1021/ac202028g.

12. Hindson CM, Chevillet JR, Briggs HA, Gallichotte EN, Ruf IK, Hindson BJ, et al. Absolute quantification by droplet digital PCR versus analog real-time PCR. Nat Methods. 2013;10:1003-5. https://doi.org/10.1038/nmeth.2633.

13. Cao L, Cui X, Hu J, Li Z, Choi JR, Yang Q, et al. Advances in digital polymerase chain reaction ( $\mathrm{dPCR}$ ) and its emerging biomedical applications. Biosens Bioelectron. 2017;90:459-74. https://doi.org/10. 1016/j.bios.2016.09.082.

14. Gutiérrez-Aguirre I, Rački N, Dreo T, Ravnikar M. Droplet digital PCR for absolute quantification of pathogens. Methods Mol Biol (Clifton, N.J.). 2015, 1302:331-47. https://doi.org/10.1007/978-1-4939-2620-6_24.

15. Takayama Y, Matsui H, Adachi Y, Nihonyanagi S, Wada T, Mochizuki J, et al. Detection of Streptococcus agalactiae by immunochromatography with group B streptococcus-specific surface immunogenic protein in pregnant women. J Infect Chemother. 2017;23:678-82. https://doi.org/10.1016/j.jiac. 2017.07.001. 
16. Ku LC, Boggess KA, Cohen-Wolkowiez M. Bacterial meningitis in infants. Clin Perinatol. 2015;42:29-45, vii-viii. https://doi.org/10.1016/j.clp.2014.10.004.

17. Clementi M, Bagnarelli P. Are three generations of quantitative molecular methods sufficient in medical virology? Brief review. New Microbiologica. 2015;38:437-41.

18. Ferreira MB, de-Paris F, Paiva RM, Nunes LS. Assessment of conventional PCR and real-time PCR compared to the gold standard method for screening Streptococcus agalactiae in pregnant women. Brazilian J Infect Dis. 2018;22: 449-54. https://doi.org/10.1016/j.bjid.2018.09.005.

19. Herring E, Kanaoka S, Tremblay E, Beaulieu JF. Droplet digital PCR for quantification of ITGA6 in a stool mRNA assay for the detection of colorectal cancers. World J Gastroenterol. 2017;23:2891-8. https://doi.org/10. 3748/wjg.v23.i16.2891

20. Zhao Y, Xia Q, Yin Y, Wang Z. Comparison of Droplet Digital PCR and Quantitative PCR Assays for Quantitative Detection of Xanthomonas citri Subsp. citri. PloS one. 2016;11:e0159004. https://doi.org/10.1371/journal. pone. 0159004

21. Guo XG, Zhou YZ, Li Q, Wang W, Wen JZ, Zheng L, et al. Rapid and reliable diagnostic method to detect Zika virus by real-time fluorescence reverse transcription loop-mediated isothermal amplification. AMB Express. 2018;8: 60. https://doi.org/10.1186/s13568-018-0591-6.

22. Vieira LL, Perez AV, Machado MM, Kayser ML, Vettori DV, Alegretti AP, et al. Group B streptococcus detection in pregnant women: comparison of qPCR assay, culture, and the Xpert GBS rapid test. BMC Pregnancy Childbirth. 2019;19:532. https://doi.org/10.1186/s12884-019-2681-0.

23. Carrillo-Ávila JA, Gutiérrez-Fernández J, González-Espín Al, García-Triviño E, Giménez-Lirola LG. Comparison of qPCR and culture methods for group B streptococcus colonization detection in pregnant women: evaluation of a new qPCR assay. BMC Infect Dis. 2018;18:305. https://doi.org/10.1186/ s12879-018-3208-4

24. Breeding KM, Ragipani B, Lee KD, Malik M, Randis TM, Ratner AJ. Real-time PCR-based serotyping of streptococcus agalactiae. Sci Rep. 2016;6:38523. https://doi.org/10.1038/srep38523.

25. Frias M, Rivero-Juarez A, Tellez F, Palacios R, Jimenez-Arranz A, Pineda JA, et al. Evaluation of hepatitis C viral RNA persistence in HIV-infected patients with long-term sustained virological response by droplet digital PCR. Sci Rep. 2019;9:12507. https://doi.org/10.1038/s41598-019-48966-9.

\section{Publisher's Note}

Springer Nature remains neutral with regard to jurisdictional claims in published maps and institutional affiliations.

Ready to submit your research? Choose BMC and benefit from:

- fast, convenient online submission

- thorough peer review by experienced researchers in your field

- rapid publication on acceptance

- support for research data, including large and complex data types

- gold Open Access which fosters wider collaboration and increased citations

- maximum visibility for your research: over $100 \mathrm{M}$ website views per year

At BMC, research is always in progress.

Learn more biomedcentral.com/submissions 